\title{
KETEPATAN PENGGUNAAN MEDIA PEMBELAJARAN UNTUK PEMBELAJARAN BAHASA INGGRIS PADA PELAKSANAAN TEACHING PRACTICE DI STBA PONTIANAK
}

\author{
ACCURACY OF THE USE OF LEARNING MEDIA FOR LEARNING \\ ENGLISH IN THE IMPLEMENTATION OF TEACHING PRACTICE AT \\ STBA PONTIANAK
}

Irma Manda Negara

STBA Pontianak

irmamanda23@gmail.com

\begin{abstract}
ABSTRAK
Penelitian ini bertujuan untuk mendeskripsikan tentang ketepatan media pembelajaran yang digunakan oleh mahasiswa pada saat pelaksanaan teaching practice. Tujuan pelaksanaannya untuk memberikan bekal kepada mahasiswa sebelum melakukan Praktik Kerja Lapangan (PKL). Penelitian ini menggunakan pendekatan deskriptif, dengan menggunakan purposive sampling dalam pemilihan subjek penelitian yang mana menyesuaikan dengan tujuan penelitian. Teknik pengumpulan datanya menggunakan checklist observasi kelas dengan skala guttman yang dilakukan oleh observer. Dengan pilihan jawaban "ya" mempunyai skor 1 dan "tidak" mempunyai skor 0. Materi-materi yang diterapkan dalam pelaksanaan teaching practice merupakan pembelajaran bahasa Inggris untuk semua tingkatan pendidikan. Dari hasil penelitian didapat dari lima kelompok berdasarkan metode pembelajaran yang sudah ditetapkan, ada dua kelompok metode yang masuk dalam kategori "sangat tepat" yaitu metode silentway dan metode SLT. Kelompok metode TPR masuk dalam kategori "tepat". Metode audio lingual dan kelompok metode SLT masuk dalam kategori "kurang tepat". Hal ini disebabkan mahasiswa lebih berfokus pada penerapan metode pembelajaran, sehingga mahasiswa tidak menggunakan media pembelajaran sama sekali. Dapat disimpulkan bahwa begitu pentingnya peran media pembelajaran, karena dapat menampilkan visualisasi dari suatu objek. Sehingga membantu dalam meningkatkan pemahaman, khususnya untuk pengenalan kosakata-kosakata baru.
\end{abstract}

Kata Kunci: Media Pembelajaran, Pembelajaran Bahasa Inggris, Teaching Practice

\section{ABSTRACT}

This study aims to describe the accuracy of the learning media used by students when implementing teaching practices. The purpose of the implementation is to provide provisions to students before conducting internship. This research used a descriptive approach, using purposive sampling in selecting research subjects which adjust to the research objectives. The data collection technique used a classroom observation checklist with a guttman scale conducted by the observer. 
Tuah Talino

Tahun XIV Volume 14 Nomor 1 Edisi 31 Juli 2020

ISSN 0216-079X E-ISSN 2685-3043

Balai Bahasa Kalimantan Barat

With the answer choices "yes" has a score of 1 and "no" has a score of 0. Material that is applied in the implementation of teaching practice is learning English for all levels of education. From the research results obtained from five groups based on predetermined learning methods, there are two groups of methods that fall into the category of "very appropriate" namely the silentway method and the SLT method. The TPR method group is included in the "appropriate" category. The lingual audio method and the SLT method group fall into the "inappropriate" category. This is because students are more focused on the application of learning methods, so students do not use learning media at all. It can be concluded that the role of learning media is so important, because it can display the visualization of an object. So that helps in increasing understanding, especially for the introduction of new vocabulary.

Keywords: Learning Media, English Language Learning, Teaching Practice

\section{PENDAHULUAN}

STBA Pontianak merupakan salah satu perguruan tinggi swasta berfokus pada Bahasa Inggris yang mempunyai dua jurusan, yaitu sastra Inggris dan pengajaran. Dengan memiliki keminatan pengajaran, STBA Pontianak mempersiapkan lulusan yang mencetak calon tenaga pendidik dalam bidang bahasa Inggris. Oleh karena itu, didalam kurikulum STBA Pontianak, terdapat beberapa mata kuliah yang mempelajari tentang pendidikan dan pembelajaran, diantaranya adalah English Teaching Method dan English Language Teaching Media (ELT-Media). Berdasarkan hasil pengamatan, dosen pengampu mata kuliah melaksanakan teaching practice di empat pertemuan pada minggu-minggu terakhir semester. Adapun tujuan pelaksanaannya selain sebagai pengayaan, pelaksanaan teaching practice juga untuk memberikan bekal kepada mahasiswa sebelum melakukan Praktik Kerja Lapangan (PKL). Setelah melakukan teaching practice, diharapkan pada saat PKL mahasiswa dapat melaksanakan pembelajaran secara efektif dan dapat menerapkan classroom management dengan baik. Seperti yang dikemukan oleh Ngidi \& Sibaya, (2003:18); Marais \& Meier, (2004:220); Perry, (2004:2) teaching practice merupakan komponen penting untuk menjadi seorang guru, karena memberikan pengalaman dengan lingkungan belajar mengajar yang sesungguhnya.

Pelaksanaan teaching practice sangat membantu dalam meningkatkan keterampilan mengajar dan kesiapan mengajar mahasiswa. Hal ini diungkapkan berdasarkan hasil penelitian yang dilakukan oleh Setiawan dan Mulyati (2018) mengemukakan bahwa terdapat pengaruh positif efektivitas pembelajaran keterampilan mengajar terhadap kesiapan mengajar dan keterampilan mengajar mahasiswa. Dapat diartikan bahwa semakin efektif dan baik keterampilan mengajar maka kesiapan mengajar dan keterampilan mengajar mahasiswa akan semakin baik. Kemudian, penelitian yang dilakukan oleh Etty (2012) dengan judul "efektivitas Pengajaran Mikro di STAIN Samarinda" menunjukkan bahwa pembelajaran mikro di Tarbiyah STAIN Samarinda efektif dan dapat menunjukkan kemampuan mengajar siswa. Dengan pelaksanaan pembelajaran mikro mahasiswa dapat membuat rencana mengajar, mempraktikkan keterampilan 
mengajar secara terpadu, pengetahuan tentang cara mengajar bertambah, serta mengetahui hal-hal yang perlu diperbaiki.

Pelaksanaan teaching practice bisa dijadikan sarana untuk memberikan bimbingan dan motivasi kepada mahasiswa meningkatkan keterampilan mengajarnya untuk dapat menciptakan pelaksanaan pembelajaran yang efektif dengan pemantauan dosen. Karena untuk mewujudkan kegiatan pembelajaran yang efektif tidaklah mudah, karena dipengaruhi oleh beberapa faktor yaitu guru, karakteristik peserta didik, serta metode dan media pembelajaran yang digunakan.

Bahasa Inggris merupakan bahasa kedua di Indonesia yang tidak mudah bagi semua orang untuk mempelajarinya. Menurut Megawati (2016) masih ditemukan masalah dalam proses pembelajarannya. Berdasarkan hasil penelitian yang sudah dilakukan oleh Megawati, ditemukan bahwa siswa mengalami kesulitan belajar bahasa Inggris. Oleh karena itu, dalam pengenalan dan penerapannya di dalam pembelajaran, guru dituntut mempunyai kemampuan untuk bisa menciptakan situasi kondisi pembelajaran yang menyenangkan dan efektif, serta melibatkan semua komponen-komponen yang ada dalam pembelajaran (Megawati, 2016). Lima komponen yang terdapat dalam pembelajaran dan saling berkaitan, salah satunya adalah media pembelajaran. Dapat dikatakan media pembelajaran merupakan suatu alat yang digunakan dalam pelaksanaan pembelajaran sebagai sarana untuk menyampaikan informasi guna menarik perhatian dan minat siswa untuk belajar yang dapat membantu dalam memahami dan mengerti materi pembelajaran yang disampaikan oleh guru dengan mudah, guna terselenggaranya pembelajaran efektif dan tercapainya tujuan pembelajaran.

Djamarah \& Zain (2006:120) menyatakan bahwa media pembelajaran adalah alat bantu apa saja yang dapat dijadikan sebagai penyalur pesan guna mencapai tujuan pembelajaran. Definisi lain dari media pembelajaran yaitu merupakan segala sesuatu alat yang berbentuk rangsangan yang disediakan guru agar siswa dapat termotivasi untuk belajar dengan cepat, tepat, mudah, benar dan untuk tidak terjadinya verbalisme. (Hanafiah \& Shana, 2010:59). Dengan demikian, dari penjabaran tersebut dapat disimpulkan media pembelajaran adalah segala sesuatu alat atau sarana yang disediakan dan digunakan oleh guru, yang penggunaannya diintegrasikan sesuai dengan tujuan pembelajaran, sehingga dapat meningkatkan motivasi belajar dan membantu dalam proses pembelajaran.

Dalam proses pembelajaran, media pembelajaran berfungsi sebagai perantara pembawa informasi dari pengirim informasi kepada penerima, dalam hal ini adalah guru dan siswa guna mencapai tujuan serta hasil belajar yang baik. Miarso, Y (2007) membatasi "media pengajaran sebagai segala sesuatu yang dapat digunakan untuk merangsang pikiran, perasaan, perhatian, dan kemauan siswa sehingga mendorong terjadinya proses belajar pada diri siswa". Dapat dikatakan bahwa media pengajaran memberikan pengaruh positif untuk meningkatkan kemauan belajar pada siswa. Media pembelajaran mempunyai fungsi utama yaitu untuk mempermudah bagi guru dalam penyampaian materi, serta membantu siswa dalam mendapatkan tambahan pengetahuan, pengalaman, dan keterampilan (Sanaky, 2013:7). Penerapan media pembelajaran dapat membantu proses keefektifan proses pembelajaran serta dalam menyampaikan 
pesan informasi. Sehingga dapat membantu siswa untuk lebih mudah memahami pesan yang disampaikan dengan lebih jelas, dan yang menjadi maksud guru bisa diserap dengan baik oleh siswa.

Dalam penggunaannya, media pembelajaran memiliki beberapa manfaat, yaitu: 1) penyajian pesan dan informasi dapat diperjelas dengan penggunaan media pembelajaran, sehingga dapat membantu kelancaran proses belajar dan meningkatkan hasil belajar; 2) meningkatkan perhatian, motivasi siswa dan kemandirian dalam belajar, serta menimbulkan interaksi langsung dengan lingkungannya; 3) mengatasi keterbatasan ruang dan waktu; 4) penggunaan media pembelajaran dapat memberikan persamaan pengalaman siswa tentang peristiwa.(Arsyad, 2011:25). Dapat dikatakan manfaat media pembelajaran yaitu memberikan pengalaman yang konkrit kepada siswa dengan berinteraksi langsung dengan lingkungan dan masyarakat disekitar, sehingga mengatasi keterbatasan pengalaman yang dimiliki. Kemudian, penggunaan media pembelajaran bisa membangkitkan keinginan dan minat siswa untuk mempelajari sesuatu. Kemudian menurut Sanaky (2013:5) "media pembelajaran memiliki manfaat bagi guru dan siswa, yaitu 1) media pembelajaran dapat menghasilkan pembelajaran lebih menarik perhatian siswa sehingga menumbuhkan motivasi belajar; 2) materi pembelajaran akan lebih jelas maknanya jika menggunakan media pembelajaran, sehingga dapat dipahami serta memungkinkan siswa untuk menguasai tujuan pembelajaran dengan baik; 3) metode pembelajaran lebih variatif, tidak hanya komunikasi verbal memalui ceramah sehingga siswa tidak bosan dan guru tidak kehabisan tenaga; 4) siswa lebih banyak melakukan kegiatan belajar". Berdasarkan penjabaran tersebut, adapun manfaat media pembelajaran selain dapat meningkatkan motivasi belajar siswa, juga dapat meningkatkan aktivitas siswa dalam pembelajaran karena terciptanya pembelajaran yang lebih menarik, yang tidak berpusat pada verbalisme.

Selain itu, Nana Sudjana (2002:2) juga mengungkapkan manfaat media dalam proses belajar siswa, yaitu: 1) proses pengajaran menjadi lebih menarik sehingga dapat menumbuhkan perhatian dan motivasi belajar siswa; 2) Memperjelas makna bahan pengajaran yang disampaikan sehingga mudah untuk dapat dipahami oleh siswa, dan yang menjadi tujuan pembelajaran dapat dikuasai dengan baik; 3) metode menjadi bervariasi sehingga siswa tidak merasa bosan dan guru tidak kehabisan tenaga karena tidak hanya semata-mata melakukan komunikasi verbal; 4) siswa menjadi lebih aktif dalam mengikuti pembelajaran, tidak hanya sekedar mendegarkan penjelas guru, tetapi juga mengamati, melakukan, mendemonstrasikan, dll. Berdasarkan penjabaran beberapa pendapat ahli tersebut, dapat disimpulkan bahwa manfaat media pembelajaran dapat membantu guru dan siswa dalam kegiatan pembelajaran, guru lebih mudah dalam menyampaikan materi pembelajaran, sedangkan siswa dapat dengan mudah memahami materi yang diberikan guru. Serta dengan menggunakan media, dapat membuat siswa menjadi pembelajar yang mandiri.

Penggunaan media pembelajaran harus mempertimbangkan berdasarkan beberapa kriteria pemilihan media, tidak bisa dilakukan secara sembarangan. Seperti yang diungkapkan oleh Falahudin (2014) pemilihan media pembelajaran harus mempertimbangkan kriteria, yaitu tujuan penggunaan, sasaran penggunaan 
media, karakteristik media, waktu, biaya, dan ketersediaan. Kemudian Arsyad (2011:75) mengemukakan tentang indikator yang perlu diperhatikan dalam memilih media yang tepat yaitu: 1) media dipilih berdasarkan tujuan instruksional yang telah ditetapkan; 2) media harus selaras dan sesuai dengan kebutuhan tugas pembelajaran dan kemampuan mental siswa; 3) media yang dipilih sebaiknya dapat digunakan dimanapun dan kapanpun dengan peralatan yang tersedia disekitarnya, dalam artian media mudah digunakan, mudah diperoleh, dan mudah dibuat oleh guru sendiri; 4) guru terampil menggunakan media yang dipilih; 5) media disesuaikan dengan kelompok belajar, ada media yang tepat digunakan untuk jenis kelompok besar, kelompok sedang, kelompok kecil dan perorangan. Kemudian dinyatakan oleh Winkel (2005) pemilihan media tidak hanya melihat dari kesesuaian dengan tujuan pembelajaran saja, tetapi juga perlu mempertimbangkan beberapa faktor yaitu cost factor, avaibility factor, ketersediaan listrik, technical quality, ruangan kelas, serta kemampuan guru dalam menggunakan media. Dapat disimpulkan bahwa dalam pemilihan media pembelajaran harus mempertimbangkan aspek-aspek yang menjadi bagian dalam kegiatan pembelajaran, serta kemudahan dalam pengadaan media tersebut.

Berkenaan dengan implementasi pemilihan media, terkadang terdapat kekeliruan yang dilakukan oleh guru, yang mengakibatkan pembelajaran masih terpusat pada guru. Oleh karena itu, dalam pemilihannya perlu memperhatikan beberapa faktor. Seperti yang dikemukan oleh Mahnun (2012:32) terdapat tiga faktor dalam mengimplementasikan langkah-langkah dalam pemilihan media, yaitu: kemampuan guru, sikap inovatif guru, dan ketersediaan sarana dan prasarana. Dengan demikian, dalam merancang tujuan pembelajaran guru diharapkan bisa menyesuaikan antara karakteristik siswa, dengan materi pembelajaran yang akan disampaikan, serta dengan sarana prasarana yang tersedia. Berdasarkan hal tersebut maka kreativitas guru sangat diperlukan.

Seperti yang dijelaskan di atas, bahwa dosen melaksanakan teaching practice. Implementasi teaching practice, menerapkan lima komponen. Mahasiswa bertindak sebagai guru, teman sejawat sebagai siswa, dan menggunakan metode serta media pembelajaran. Yang menjadi tantangan dalam kegiatan ini, dosen pengampu menentukan beberapa metode, yaitu Total Physical Respond (TPR) method, SilentWay Method, Audio Lingual Method, Communicative Language Teaching (CLT), Situational Language Teaching (SLT), Kemudian mahasiswa diberi kebebasan dalam menentukan materi dan media yang akan mereka gunakan. Yang menjadi tantangannya adalah mahasiswa harus bisa mencocokkan antara materi dengan penggunaan metode dan media, sebagaimana diketahui bahwa tidak semua metode dan media cocok untuk semua materi. Prinsip pelaksanaan dari teaching practice ini seperti pengajaran mikro, yaitu pengajaran yang disederhanakan. Materi hanya terbatas pada satu kompetensi atau satu pokok bahasan materi. Berkenaan dengan waktu, alokasi waktu hanya $10-15$ menit. Berkenaan dengan tantangan yang diberikan oleh dosen pengampu mata kuliah tentang kecocokan materi dengan metode dan media, penulis mencoba melihat kemampuan mahasiswa dalam penggunaan media yang tepat yang sesuai dengan materi dan metode pada saat melaksanakan teaching practice. 
Berdasarkan pemikiran tersebut, penulis meneliti tentang: Ketetapatan Penggunaan Media Pembelajaran untuk Pembelajaran Bahasa Inggris pada Pelaksanaan Teaching Practice di STBA Pontianak. Dengan pertanyaan penelitian "Bagaimana Ketepatan Penggunaan Media Pembelajaran pada Pelaksanaan Teaching Practice". Diharapkan penelitian ini akan memberikan sumbangsih ilmu berkaitan dengan pelaksanaan teaching practice, serta kriteria pemilihan media pembelajaran yang tepat sesuai dengan materi dan metode yang digunakan. Ditinjau dari jenisnya, banyak media yang dapat dipilih dan digunakan, dikembangkan, serta dimanfaatkan yang menyesuaikan dengan situasi kondisi, waktu dan juga biaya pengadaan, termasuk tujuan pembelajaran. Masing-masing media memiliki karakteristik sendiri yang harus kita pahami terlebih dahulu sebelum digunakan. Sehingga kita sebagai pengguna dapat memilih media yang tepat, yang disesuaikan dengan kebutuhan dan kondisi yang ada dilapangan (Wiratmojo \& Sasonohardjo, 2002).

\section{METODE}

Penelitian ini menggunakan pendekatan deskriptif. Menurut Wiyono (2007) "penelitian deskriptif bertujuan untuk medeskripsikan suatu fenomena sebagaimana adanya pada waktu penelitian dilakukan". Penelitian ini dengan objektif mendeskripsikan tentang pelaksanaan teaching practice dengan berfokus pada penggunaan media pembelajaran yang dipakai oleh mahasiswa. Peneliti bertindak sebagai instrument utama dibantu observer dalam pengumpulan data serta pengumpulan dokumentasi. Pelaksanaan teaching practice dilakukan setelah mid test. Dalam pelaksanaannya, dosen memberikan kebebasan dalam pemilihan materi dan media pembelajaran yang digunakan, tetapi dosen menentukan metode pembelajaran yang harus diimplementasikan dalam teaching practice. Metode yang harus diterapkan adalah Total Physical Respond (TPR) method, SilentWay Method, Audio Lingual Method, Communicative Language Teaching (CLT), Situational Language Teaching (SLT). Dosen membagi menjadi lima kelompok berdasarkan metode yang harus diterapkan.

Untuk pengumpulan data, peneliti menggunakan pengamatan dilakukan secara terbuka. Penelitian ini dilakukan di STBA Pontianak. Peneliti menggunakan purposive sampling dalam pemilihan subjek penelitian yang mana menyesuaikan dengan tujuan penelitian. Instrument penelitian menggunakan angket yang berisikan pernyataan dengan menggunakan indikator pemilihan media yang tepat. Teknik pengumpulan datanya menggunakan checklist observasi kelas dengan skala guttman yang dilakukan oleh observer. Skor 1 untuk pilihan "ya" dan skor 0 untuk pilihan "tidak". Gunanya untuk menarik kesimpulan presentase tentang ketepatan pemilihan media yang digunakan. Selanjutnya penelitian ini menggunakan reduksi data, penyajian data, dan menarik kesimpulan sebagai teknik analisis data. Adapun instrument penelitian menggunakan seperti dibawah ini: 
Tabel 1 Instrumen Penelitian

\begin{tabular}{|c|l|c|c|}
\hline No & \multicolumn{1}{|c|}{ Indikator } & Ya & Tidak \\
\hline 1 & Kesesuaian media dengan tujuan pembelajaran & & \\
\hline 2 & Kesesuaian media dengan materi pembelajaran & & \\
\hline 3 & Kesesuaian media dengan kebutuhan peserta didik & & \\
\hline 4 & Kesesuaian media dengan metode pembelajaran & & \\
\hline 5 & Media pembelajaran mudah digunakan & & \\
\hline 6 & Kesesuaian media dengan kelompok belajar & & \\
\hline
\end{tabular}

Satu orang mahasiswa, jika memenuhi semua indikator mendapat point 6 . Kemudian total skor dan persentase, jika jumlah dalam satu kelompok beranggotakan 6 orang mahasiswa, maka skor maksimal adalah 36. Sedangkan jika jumlah dalam satu kelompok beranggotakan 7 orang mahasiswa, maka skor maksimal adalah 42. Data yang dikumpulkan kemudian dianalisis dengan menggunakan rumus berikut:

Indeks $(\%)=($ skor total $/ \mathrm{Y}) \times 100 \%$

Dengan interpretasi skor:

Tabel 2 Interpretasi Skor

\begin{tabular}{|c|c|}
\hline Interval $(\%)$ & Interpretasi \\
\hline $85-100$ & Sangat tepat \\
\hline $70-84$ & Tepat \\
\hline $51-69$ & Kurang tepat \\
\hline $30-50$ & Tidak tepat \\
\hline
\end{tabular}

\section{PEMBAHASAN}

Pada pelaksanaan praktinya, mahasiswa dibagi menjadi lima kelompok berdasarkan metode pembelajaran yang digunakan, dimana rata-rata satu kelompok beranggotakan 7 orang. Masing-masing group menggunakan metode pembelajaran yang sudah ditentukan berdasarkan hasil undi. Pada saat pelaksanaan teaching practice seringnya terjadi kegaduhan, karena antusias mahasiswa dan merupakan pengalaman mereka mengajar didepan kelas. Semua mahasiswa, sebelum tampil sudah menyiapkan rancangan pembelajaran masingmasing yang mereka deskripsikan dalam RPP. Hampir 50\% mahasiswa menyiapkan rencana pembelajaran bahasa inggris untuk tingkat $\mathrm{TK}$, sehingga konsepnya lebih menekankan pada belajar sambil bermain. Berdasarkan hasil checklist observasi kelas, didapat: 
Tabel 3 Hasil Analisis Data

\begin{tabular}{|c|c|c|c|c|}
\hline No & Metode Pembelajaran & $\begin{array}{l}\text { Total } \\
\text { Skor }\end{array}$ & $\begin{array}{l}\text { Persentase } \\
(\%)\end{array}$ & Keterangan \\
\hline 1 & $\begin{array}{l}\text { Total Physical Respond } \\
\text { (TPR) method ( } 6 \\
\text { Mahasiswa) }\end{array}$ & 26 & 72.2 & $\begin{array}{l}\text { - Materi untuk } \\
\text { pembelajaran tingkat } \\
\text { SMP, tetapi media yang } \\
\text { digunakan untuk tingkat } \\
\text { anak-anak } \\
\text { - Tampilan media yang } \\
\text { digunakan kurang besar, } \\
\text { sehingga tidak terlihat } \\
\text { dengan jelas untuk siswa } \\
\text { yang duduk dibagian } \\
\text { belakang } \\
\text { - Media yang digunakan } \\
\text { tidak cocok untuk } \\
\text { kelompok belajar yang } \\
\text { besar }\end{array}$ \\
\hline 2 & $\begin{array}{ll}\text { SilentWay } & \text { Method } \quad(7 \\
\text { Mahasiswa) } & \end{array}$ & 38 & 90.5 & $\begin{array}{l}\text { Media yang digunakan } \\
\text { tidak sesuai dengan } \\
\text { prinsip pelaksanaan } \\
\text { metode silentway } \\
\text { - Siswa kurang menaruh } \\
\text { perhatian lebih pada } \\
\text { media yang digunakan, } \\
\text { sehingga mempengaruhi } \\
\text { pada keefektifan } \\
\text { pembelajaran }\end{array}$ \\
\hline 3 & $\begin{array}{l}\text { Audio Lingual Method (7 } \\
\text { Mahasiswa) }\end{array}$ & 24 & 57.1 & $\begin{array}{l}\text { Mahasiswa mengajar } \\
\text { tanpa menggunakan } \\
\text { media, lebih berfokus } \\
\text { pada implementasi } \\
\text { metode pembelajaran }\end{array}$ \\
\hline 4 & $\begin{array}{l}\text { Communicative Language } \\
\text { Teaching (CLT) } \\
\text { Mahasiswa) }\end{array}$ & 18 & 42.9 & $\begin{array}{l}\text { Mahasiswa mengajar } \\
\text { tanpa menggunakan } \\
\text { media, lebih berfokus } \\
\text { pada implementasi } \\
\text { metode pembelajaran }\end{array}$ \\
\hline 5 & $\begin{array}{l}\text { Situational Language } \\
\text { Teaching (7 Mahasiswa) }\end{array}$ & 36 & 85.7 & $\begin{array}{l}\text { Materi yang } \\
\text { disampaikan tidak cocok } \\
\text { dengan metode } \\
\text { pembelajaran dan media } \\
\text { yang digunakan }\end{array}$ \\
\hline
\end{tabular}


Dari penjabaran di atas, maka dapat dikatakan bahwa dari lima kelompok berdasarkan metode pembelajaran yang sudah ditetapkan, ada dua kelompok metode yang masuk dalam kategori "sangat tepat" yaitu metode silentway dan metode SLT. Kelompok metode TPR masuk dalam kategori "tepat". Metode audio lingual dan kelompok metode SLT masuk dalam kategori "kurang tepat". Hal ini disebabkan mahasiswa lebih berfokus pada penerapan metode pembelajaran, sehingga mahasiswa tidak menggunakan media pembelajaran sama sekali. Sebagian besar mahasiswa menerapkan pembelajaran sambil bermain, karena materi yang diajarkan lebih banyak untuk tingkatan Sekolah Dasar.

Berdasarkan hasil tabel diatas dapat ditarik kesimpulan bahwa: untuk metode TPR, ketepatan penggunaan media pembelajaran sebesar $72.2 \%$. Hal ini dapat dikatakan bahwa mahasiswa cenderung tepat dalam menggunakan media pembelajaran, walaupun ada catatan bahwa media yang digunakan tidak sesuai dengan kebutuhan siswa dan tidak cocok digunakan untuk kelompok belajar yang besar. Untuk metode silentway, ketepatan penggunaan media pembelajaran sebesar 90.5\%. Dapat disimpulkan bahwa mahasiswa sangat tepat dalam menggunakan media pembelajaran. Untuk kelompok ini, ada beberapa catatan yaitu media yang digunakan tidak sesuai dengan metode silentway yang mana pada metode ini guru lebih banyak diam dan hanya memberikan instruksiinstruksi mengenai objek yang sedang dipelajari. Tetapi dalam pelaksanaannya justru guru yang lebih mendominasi. Kemudian untuk mahasiswa lainnya, kurang menguasai metode dan media yang digunakan, dan kurang melibatkan audience untuk aktif dalam proses pembelajaran. Hal ini memberikan dampak audience kurang menaruh perhatian lebih sehingga mempengaruhi keefektifan proses pembelajaran.

Metode selanjutnya adalah metode audio lingual, untuk metode ini berdasarkan hasil pengamatan dan checklist. Hampir 50\% mahasiswa tidak menggunakan media pembelajaran, mereka lebih focus pada penerapan metode pembelajarannya. Dimana tujuan dari metode ini lebih menekankan pada pengulangan pengucapan dan penghafalan. Sedangkan untuk sisanya, mahasiswa cenderung sudah tepat menggunakan media pembelajarannya, yang disesuaikan dengan materi dan metode yang telah ditetapkan. Salah satunya adalah menggunakan media PowerPoint berbantu LCD Projector, dimana tampilannya berisi beberapa dialog, dan audience diperintahkan untuk mengulangi apa yang diucapkan oleh pelakon (guru) sesuai dengan isi tampilan media. Untuk metode CLT, hanya dua orang saja yang menggunakan media pembelajaran. Dalam hal ini sama dengan metode sebelumnya, mahasiswa hanya menekankan pada penerapan metode pembelajarannya saja, dimana untuk metode ini penerapannya lebih menekankan pada penggunaan bahasa, sehingga yang dilakukan mahasiswa, lebih banyak pada latihan berbicara. Untuk yang menggunakan media pembelajaran, sebagian dari mereka menggunakan media flash card dan menggunakan cara bermain, dimana audience membuat percakapan singkat sesuai dengan gambar yang diambil oleh masing-masing kelompok. Sedangkan sebagian lainnya menggunakan media LCD Projector.

Metode yang terakhir adalah metode SLT. Pada metode hampir 90\% mahasiswa menggunakan media pembelajaran yang tepat sesuai dengan metode 
dan materi yang disampaika. Pada metode ini mahasiswa menggunakan media pembelajaran pembelajaran interaktif, dan juga menggunakan media realia sebagai pengenalan kosakata baru, disesuaikan dengan materi yang disampaikan. Tetapi, ada satu orang mahasiswa yang salah dalam menempatkan materi. Materi yang disampaikan tidak cocok dengan metode dan media pembelajaran yang digunakan, sehingga memberikan dampak, audience menjadi bingung untuk mengikuti pembelajaran yang sedang dipraktekkan. Ditarik kesimpulan secara keseluruhan, masih terdapat beberapa mahasiswa yang tidak menggunakan media pembelajaran, dikarenakan lebih menekankan pada penerapan metode. Bahkan ada salah satunya yang salah dalam penempatan materi dengan metode pembelajaran, dan tidak menggunakan media pembelajaran. Kesimpulan berikutnya adalah, begitu pentingnya peran media pembelajaran, karena dapat menampilkan visualisasi dari suatu objek. Sehingga membantu dalam meningkatkan pemahaman, khususnya untuk pengenalan kosakata-kosakata baru.

Dapat dikatakan bahwa peran penting dalam ketepatan dalam pemilihan media ini adalah kreativitas pengajar. Bagaimana pengajar bisa mengembangkan media pembelajaran yang disesuaikan dengan indikator-indikator dalam pemilihan media. Seperti yang dijelaskan oleh Arsyad (2011) media pembelajaran dipilih berdasarkan tujuan instruksional. Oleh karena itu, pentingnya seorang untuk merancang pembelajarannya langsung. Karena pengajar yang lebih mengetahui output yang diharapkan setelah materi tersampaikan secara utuh, yang disesuaikan dengan kurikulum yang ada. Kemudian, menurut Arsyad juga, media pembelajaran sebaiknya mudah dibuat, diperoleh, dan digunakan. Hal ini dapat dikatakan bahwa media pembelajaran yang digunakan harus bersifat efektif dan efisien. Serta didikung oleh saran dan prasarana yang tersedia, sehingga media pembelajaran dapat digunakan dalam jangka waktu panjang. Selanjutnya dikatakan juga media pembelajaran disesuaikan dengan kelompok belajar. Tidak semua media pembelajaran cocok untuk segala kondisi, oleh karena itu dalam mendesain media pembelajaran pengajar perlu memperhatikan dimensi media. Dalam artian ukuran media, dimensi gambar dan tulisan harus bisa terlihat jelas oleh peserta didik/audience.

\section{PENUTUP}

Berdasarkan hasil analisis penelitian, disimpulkan bahwa jika dikomulatifkan secara persentase dari ketepatan penggunaan media pembelajaran yang disesuaikan dengan metode pembelajaran dan materi yang disampaikan, didapat rata-rata $69.68 \%$. Hal ini menunjukkan bahwa tingkat ketepatan penggunaan media dalam teaching practice masih masuk dalam kategori kurang tepat. Hal ini dikarenakan ada pada beberapa metode, mahasiswa hanya berfokus pada implementasi metode pembelajaran untuk mencapai tujuan pembelajaran yang tertera. Selain itu juga, masih ada beberapa mahasiswa yang masih kesulitan dalam time management, karena teaching practice hanya memerlukan $10-15$ menit. Menyebabkan pada saat pelaksanaan praktek, melewati batas waktu maksimum yang sudah ditetapkan. 
Media pembelajaran sebagai salah komponen pembelajaran yang tidak diabaikan. Dengan menggunakan media pembelajaran, didapati mahasiswa yang berperan sebagai audience/siswa lebih menaruh perhatian lebih terhadap berlangsungnya proses pembelajaran yang disampaikan oleh rekan sejawatnya yang sedang tampil. Sehingga proses pembelajaran menjadi kooperatif. Dalam pemilihan media pembelajaran, sebaiknya menyesuaikan dengan karakteristik peserta didik, dimensi dari media pembelajaran yang digunakan, sarana dan prasarana yang tersedia, serta efektifvitas dan efisiensi dari media itu sendiri.

\section{UCAPAN TERIMA KASIH}

Pada kesempatan ini, penulis memberikan ucapan terima kasih kepada ibu Mita Nur Aflah, S.Pd., M.Pd. yang membantu dalam pelaksanaan penelitian ini selaku observer. Serta memberikan saran dalam skema pelaksanaan teaching practice.

\section{DAFTAR PUSTAKA}

Arsyad, A. (2011). Media Pembelajaran . Jakarta: PT RajaGrafindo Persada. Djamarah, \& Zain. (2006). Media Pembelajaran. Jakarta: Rineka Cipta.

Etty, N. (2012). Efektivitas Pengajaran Mikro di STAIN Samarinda. Jurnal Pendidikan Fenomena, 187-201.

Falahudin, I. (2014). Pemanfaatan Media dalam Pembelajaran. Jurnal Lingkar Widyaiswara, 104-117.

Hanafiah, \& Suhana. (2010). Konsep Strategi Pembelajaran. Bandung: PT Refika Aditama.

Mahnun, N. (2012). Media Pembelajaran (Kajian Terhadap Langkah-Langkah Pemilihan Media dan Implementasinya dalam Pembelajaran). Jurnal Pemikiran Islam, 27-35.

Megawati, F. (2016). Kesulitan Mahasiswa Dalam Mencapai Pembelajaran Bahasa Inggris Secara Efefktif . Jurnal Pedagogia, 147 - 156.

Meier, P., \& Marais , C. (2004). Hear Our Voice: Student teacher's experience during practical teaching. Africa Education Review, 220-233.

Miarso, Y. (2007). Menyemai Benih Teknologi Pendidikan. Jakarta: Prenada Media Group.

Ngidi, D., \& Sibaya, P. (2003). student Teacher Anxieties Related to Practice Teaching. South African Journal of Education, 18-22.

Sanaky, A. (2013). Media Pembelajaran Interaktif-Inovatif . Yogyakarta: Kaukuba Dipantara.

Setiawan, I., \& Mulyati, S. (2018). Efektivitas Mata Kuliah Pembelajaran Mikro (Microteaching) Terhadap Keterampilan Dasar Mengajar dan Kesiapan Mengajar. Jurnal Penelitian Pendidikan dan Ekonomi, 51-60.

Sudjana, N. (2002). Penilaian Hasil Proses Belajar Mengajar. Bandung: Remaja Rosdakarya.

Winkel, W. (2005). Psikologi Pengajaran. Yogyakarta: Media Abadi. 
Tuah Talino

Tahun XIV Volume 14 Nomor 1 Edisi 31 Juli 2020

ISSN 0216-079X E-ISSN 2685-3043

Balai Bahasa Kalimantan Barat

Wiratmojo, P., \& Sasonohardjo. (2002). Media Pembelajaran Bahan Ajar Diklat Kewidyaiswaraan Berjenjang Tingkat Pertama. Jakarta: Lembaga Administrasi Negara.

Wiyono, \& Bambang, B. (2007). Metodologi Penelitian. Malang: Universitas Negeri Malang. 